\title{
"Better a barefoot than none": Influences of Nationalist ideologies on girlhood in the history classroom
}

\author{
Y Woest \\ University of Pretoria,Pretoria, South Africa \\ Orcid: 0000-0001-5595-0546 \\ yolandi.woest@up.ac.za \\ DOI: http://dx.doi.org/10.17159/2223-0386/2021/n26a5
}

\section{Abstract}

This study adopted autoethnography as a research methodology to relive and reflect on my experiences as a White Afrikaner girl in a history class during the apartheid era in South Africa. This paper focuses on how the grand narratives of Afrikaner Nationalist ideologies and Whiteness in South Africa influenced girlhood or girl-becoming within the History classroom during apartheid in the late 1980s. This paper purposefully interrogates how ideologies of white supremacy, such as ordentlikheid (ethnicised respectability), found their way into the micro-context of a primary school history classroom through small acts of oppression. Epistemologically, I underpin this this paper by an interpretative paradigm to justify the meaning-making of personal experiences, which form the core of this paper. Methodologically, the study adopted a qualitative approach, and the research design comprised of an autoethnography. Data consisted of a personal narrative developed from a reflective piece of personal free writing into a crafted story by relying on memory work and checked by verisimilitude to remember specific details. I was the sole participant in that I generated the data through my narrative. An analysis of the findings showed 'place' as predominant convergence of identity marker, namely the place of 'outsider-girlhood' within the socio-educational context and intersectionality as Nationalist influence on white girlhood. I conclude the paper with my final reflections as a form of meaning-making.

Keywords: Afrikaner; Autoethnography; White girlhood; History education; Role-play, Whiteness. 


\section{Introduction}

It was allegedly Gabrielle Bonheur Chanel, whom we might know better as Coco Chanel, who said, 'a woman with good shoes is never ugly'. It is easy to believe a fashion icon such as Coco Chanel with her tremendously successful career. Winnie Madikizela Mandela describes how her first pair of shoes, although very painful to wear, inspired her lifelong fascination with shoes and clothing against poverty and white oppression (Du PreezBezdrob, 2003). In certain religions and cultures, the act of removing one's shoes when approaching a sacred person or place is a mark of reverence and respect for the hospitality of the host. In other cultures, the opposite is also true. For example, in the Middle East, it is traditionally considered highly insulting to hit someone with the bottom of a shoe, which is considered to be dirty. To show the sole of your shoe and throwing shoes to someone in the Arab world are signs of extreme disrespect (Curtis, 2018). Shoes also have a strong religious connotation, and the Bible is rife with symbolic references to shoes. Moses was instructed to remove his shoes before approaching the burning bush (Exodus 3:2). The anger of God is shown by the Psalmist writing, "Over Edom, I shall throw My shoe" (Psalm 108:9). Solomon describes the beauty of the feet in the sandals of the prince's daughter (Song of Solomon 7:1), and Isaiah writes about the boots of warriors in battle (Isaiah 9:5).

In some cultures, empty shoes symbolise death. During the tenth-anniversary memorial of the September 11 attacks in the USA, 3000 pairs of shoes represented those killed. The Jews who were massacred by Fascist Hungarian militia in Budapest during the Second World War are honoured by the memorial erected on the east bank of the Danube River in Budapest, Hungary (Curtis, 2018). The shoes represent the Jews who had to take off their shoes before being shot at the edge of the river so that their bodies could fall in the water and be carried away. Figuratively, shoes got a foot in the door of Western civilization and culture and became an integral part of a culture, social practices, arts, and the stories we tell.

This autoethnographic paper tells the story of a 'shoe-less girl' within a specific racial-socio-political context in the South African educational space of the late 1980s. The National Party's national education curriculum at the time, explicitly and implicitly, became a powerful tool. Through the curriculum, they entrenched Nationalist ideologies using distorted content, learning opportunities, standards, learning, and teaching support material, pedagogies, and the contexts in which the curriculum was enacted as part of Christian National Education (CNE) (Fogle-Donmoyer, 2017; Isaacs, 2016). The 'vehicles of policing' to ensure white exclusive and separatist education, and a distorted curriculum 
based on race, were usually white Afrikaans-speaking men who strategically controlled national and provincial policy formulation and its implementation in the classroom. Against this background, the paper's focus is on the influence of Nationalist ideologies on girlhood during the apartheid regime in 1989. The purpose of the paper is to interrogate the impact and effects of this strategic control as it manifested in the micro-context of a history classroom. Firstly, I provide a theoretical backdrop to situate the paper within the relevant existing scholarly literature. Secondly, I describe autoethnography as a research methodology. Afterward, I give an autoethnographic account of the critical event that inspired the writing of this paper and served as a data generation method. Next, I engage deeply with the data by analysing and discussing the data and relevant scholarly literature. I conclude the paper with a final, personal reflection.

\section{The literary and theoretical backdrop to the paper}

In this section, I provide the academic background to my paper. I focus on three concepts: girlhood studies, white women and girls, and the Afrikaner volksmoeder ideology.

\section{Girlhood studies}

My paper focuses on the broader scholarly field of girlhood studies. Previously, several researchers have combined studies about boys and girls, assuming that the experiences of these groups are similar (Mendes, Silva, Duits, Zoonen, Lamb \& Edwards, 2009). However, since the rise of feminism in 1970, more studies about girls as a unique group have emerge. Some of the aspects that have interested girlhood researchers during the last four decades are girls' lives, sexualities, identities, roles, and interests in society, education, and popular culture, among others (Mendes et al., 2009). More recent research on girls interrogated their consumption of cultural products and cases where girls brought forth their own popular culture in response to existing popular cultures in various societies (Duits \& Van Romondt Vis, 2009). However, mainly conducted in Europe and the United States, most studies focused on white, privileged girls from middle-class families. In support, De Finney (2015) believes that girlhood studies continue to be primarily hetero-normative and Eurocentric, which aligns with the findings from my literature review on girlhood studies.

My distinct memory and the increasing scholarship in girlhood, which challenges hetero-, gender- and race-normative conceptualisations, inspired this study. International literature on girlhood studies abroad seems to be growing. More recent international 
studies show a strong tendency towards the inclusion of the lived experiences of black girls. Until recently, historians interested in black girls and girlhood had to work at the margins of several fields, including the history of childhood, black women's history, and girls' studies (Field, Owens, Chatelain, Simmons, George, and Keyse, 2016). This notion appears to be changing since international interdisciplinary studies about 'black' girlhood seemed to have become more prominent. International studies on girlhood include aspects such as intergenerational relations, structural, macro-, and micro-contexts of girls' experiences that shape gender as a biased embodiment and modern girlhood, indigenous girlhood, and black girlhood studies across education disciplines (De Finney, 2015; McLeod, 2014; Owens, Callier, Robinson \& Garner, 2017). The Covid-19 pandemic has influenced the field of girlhood studies and ignited various studies about girls related to the pandemic (Bellerose, Diaw, Pinchoff, Kangwana \& Austrian, 2020; Copley, Decker, Delavelle, Goldstein, O’Sullivan \& Papineni, 2020).

Post-1994, South Africa gave birth to various studies and reports about women and girls across a broad spectrum, ranging from their sexual behaviour, females as primary victims of gender-based violence, their role in science and technology, and their contribution to the history of a country (De Finney, 2015; Mitchell \& Rentschler, 2016). Other aspects that South African researchers on girlhood wrote about include girls' roles in decolonisation, academic success and school culture, girls' sexualities, and the role and effect of politics on girls (Mitchel \& Rentschler, 2016). One study was conducted about the influence of the Covid-19 pandemic on South African girls (Mitchell \& Smith, 2020). It seems as if research on white girlhood studies has not ultimately made its way into South Africa. Consequently, there appears to be a silence in South African literature especially about, what I call 'white girlhood' and white girls. Much has been written about the Afrikaner volksmoeder, and the notion of the volksmoeder holds an important place in historical research about the Afrikaner volk (Du Toit, 2003; Van der Westhuizen, 2007, 2017; Prescott, Rees, \& WeaverHightower, 2021). Yet, there is limited focus on the lived experiences of the daughters of the volksmoeders. It is this presumed gap in the South African scholarship to which my study attempts to contribute. In the next section, I address the theoretical position of the volksmoeder concept.

\section{White women and girls within the context of Afrikaner nationalism}

The role of women in patriarchal societies is generally understated. However, most nationalist ideological formulations, initiated mainly by men, have generally regarded the 
role of women as paramount (Vincent, 2000; Hunter, 2021). The woman's figure as a mother recurs throughout the history of nationalist political mobilisations (Van der Westhuizen, 2016; Vincent, 2000). In Afrikaner nationalism, the symbolic figure of the woman took on the form of the volksmoeder (mother of the nation) icon, commonly assumed to describe a highly circumscribed set of women's social roles. During the South African war ${ }^{1}$ (18991902), Susanna Maritz Smit was part of a group of Afrikaner Voortrekker women involved in a dispute with a British commissioner (De Beer, 2017). During this dispute that Susanna Smit uttered the well-known words: "Rather barefoot over the mountains than to suffer under the yolk of British rule". These words encapsulate the idea of the volksmoeder idea. The concept of the volksmoeder came into being through how the ideal womanhood was depicted by society in a British context (Prescott, Rees, \& Weaver-Hightower, 2021). Womanhood extended into fanciful notions upheld by white Afrikaner women and translated into the volksmoeder ideology. The volksmoeder concept had strong connections to and was complicit with Afrikaner nationalism and Afrikaner identity (Pretorius, 2019).

The levels of conditional power granted by the volksmoeder ideology highlighted the reasoning behind the Nationalist ideology's resilience and influence on Afrikaner culture and identity (Van der Westhuizen, 2017). Women were often identified as consumers of a "male-constructed ideology" (Du Toit, 2003:155). This was expressed by women fulfilling inferior roles in a white male-dominated socio-political-economic environment through their positions in the economy and state, their clothes, language, religious activities, sexual orientation, and general behaviour. Although they were not regarded as producers of Afrikaner nationalism, they reproduced the ideology through childbearing and the cultivation of Christian, Calvinist, and Afrikaner traditions in their children, including their girl children.

The emphasis on women as mothers, not only of their own families but of all their people, held huge possibilities for women to engage in a wide range of projects outside of the private sphere of the home. Women adopted the volksmoeder role to domesticise Afrikaner nationalism in how they behaved towards white men and the volk through philanthropic, cultural, and party-political organisations. The volksmoeder concept was adapted along with society to pass on from one generation to the next. To this end, the Afrikaner woman was associated with ordentlikheid (ethicised respectability), which spoke to their femininity, heterosexuality, whiteness, and middle-class status (Van der Westhuizen, 2016; 2017).

1 The South African War is also referred to as the Boer War, Second Boer War, Anglo-Boer War, or the Second War of Independence by some Afrikaners. 
Ordentlikheid encapsulates good manners, politeness, humility, decency, and subscribing to Calvinistic principles. Van der Westhuizen (2017) further elaborates on how ordentlikheid is the face of the volksmoeder who promotes a "mode of whitening", as well as serving as a "generator of Afrikaner identity" (Van der Westhuizen, 2017: 33).

Drawing on Van der Westhuizen's analysis $(2007$; 2017), ordentlikheid is "a normative and analytical concept." British imperialism and Afrikaner nationalism adopted respectability as a nineteenth-century bourgeois European invention. Apart from tidiness and respecting others and oneself, respectability clearly distinguishes between man/ woman, heterosexual/homosexual, masculinity/femininity, and white/black (Van der Westhuizen, 2017). In a series of books written and published by two male authors, called Die Vrou (Albertyn \& Van der Merwe, 1973), they discuss Afrikaner women's ways to be 'perfect'. This series consists of a wide variety of topics, ranging from caring for your body, dressing yourself, and taking care of your house, husband, and children. Writings such as these became the basis on which Afrikaner women built their identities as mothers of the nation. Against this backdrop, white Afrikaner girl children were raised. Characteristics such as modesty, chastity, tidiness, calmness, and serenity were deeply instilled in them. The girls who did not adhere to these norms experienced various forms of punishment and ostracization. Scholarly literature about the influences of these norms on the identity of white Afrikaner girls in South Africa is limited. This paper attempts to fill the presumed gap in the literature.

\section{Afrikaner nationalism and the history curriculum}

Afrikaner nationalism as a political ideology was born in the 1870s and the first half of the 1880s among white Afrikaners in South Africa. Afrikaner identity emerged from the fear that the Afrikaans-speaking white Afrikaners or Boers occupied a "lesser white" status concerning the dominant colonial, Anglo-whites, and English aristocracy (Van der Westhuizen, 2017: 26). They were disqualified from being part of a super white race and compared with the indigenous and native people, based on their perceived indolence, ignorance, slow-wittedness, rowdiness, and living a "debauched and irregular life" (Giliomee, 2009: 22). White Afrikaner people's uncultured nature did not conform to the normative white English-speaking South African at the time, which ascribed to them a subaltern whiteness. The Afrikaners earned themselves derogatory names such as "Dutchman, "bywoner", "rock spider" and "boertjie". Although they did not want to be integrated into Englishness, there was the constant aspiration to be assimilated into the 
economic and cultural prosperity of the British (Van der Westhuizen, 2017).

Strongly influenced by anti-British views, Afrikaner nationalism was based on the premise that white Afrikaners should be the 'chosen' people, superior to other races. The Afrikaans language, Christian and Calvinist values, and most importantly, distinct segregation between races, distinguished them from the rest (Van der Westhuizen, 2007). Van der Westhuizen (2017: 32) argues that after the South African War of 1899-1902 between Great Britain and the two Boer (Afrikaner) republics, namely the South African Republic (Transvaal) and the Orange Free State, coupled with British subjugation, the Afrikaners strived to move out of the "margins of respectability," "cultural non-conformity" and "racial degeneration" by embarking on a "bourgeois gender project" to produce a superior volk, which they wanted to achieve through the segregation of races as well as Christian Nationalist Education.

During the period, most aspects and elements in the curriculum pointed towards the grand idea of the Afrikaner volk and their ideals and struggles towards superiority. Two iconic historical moments set the South African scene from which patriarchy/Nationalist ideologies/volksmoeder-idea/place of white girls stemmed. These were the Great Trek and the South African War. Central to history teaching at the time was the Great Trek of the white European emigrants. Siebörger (2018: 41) noted how South Africans who went to school before the democratic era (pre-1994) "would have no hesitation in identifying the Great Trek as the dominant narrative and prevailing public history theme in the history they experienced at school”. During the reign of the National Party from 1948-1994, the trek occupied a dominant space in the South African history curriculum. It engaged a significant amount of the content of the (then) Standard 4, 6, and 8 history curricula (Siebörger, 2018). For many teachers, the history of the Great Trek compounded by Nationalist ideologies were narratives they knew well, which spilled over into their teaching methodologies and hidden messages evident in their teaching philosophies. Textbooks and other learning and teaching support material carried messages of the Nationalist ideology throughout the entire curriculum, especially in history. Pingel (2010:7) postulates that "History and Geography textbooks attempt to explain our roots, how and why we happen to be living in a certain place and how that place can be described and characterised - in other words, who we really are”.

Central to the CNE curriculum in 1989 (the time of the narrative), was the history curriculum. Hues (2011:74) describes the school subject of history as having a "particularly pernicious ideological role under apartheid". Two key factors that played a significant role in teaching history were history textbooks and teachers. Although history textbooks 
are not the focus of this article, it is important to highlight their role in the educational context as part of the toolset with which the white-controlled state attempted to imprint apartheid ideologies on school-going learners. Colley (2017) refers to how misconceptions were created by the ways in which history educators present specific topics. He further comments on the absence of women and women's history in traditional textbooks, thereby indicating the tangential degree to which the stories of women are seen compared to the conventional political and economic histories (Colley, 2017). Through teachers, textbooks, and the hidden curriculum conveyed by both teachers and textbooks, the National Party could prolong the apartheid agenda. Even twenty-one years ago, Özkirimli (2000: 193) noted that studies of nationalism often "neglect the micro-level and that one has to look in the family and household, in the unspectacular details of everyday life". South African history classrooms in the late 1980s as educational micro-level contextual spaces were explicitly vulnerable to the manifestations of the apartheid agenda and are therefore worthy of exploration at micro-level contexts.

Bertram and Wassermann (2015) view school history textbooks as embodying "ideological messages about whose history are important, as they aim to develop both an 'ideal' citizen and teach the subject of history” (p.156). South African history textbooks were relentless teaching tools to achieve the CNE's goal of developing 'ideal' citizens. The Afrikaner Nationalist agenda allowed "little critique or critical engagement with the texts that learners studied, and teachers used to teach” (Bertram \& Wassermann, 2015: 156). In addition, history, by its status as a compulsory school subject up to Standard 7 (now Grade 9) at the time, was a comfortable vehicle to shape young, susceptible minds into identities to fit neatly into the safe cocoon of Nationalist ideals.

\section{Research methodology}

In this section, I discuss the methodological move of interrogating a critical incident of girlhood under apartheid. I discuss the research methodology and the rationale for my methodological decisions.

\section{Methodological choices}

The argument in this article is a critique of the socio-politicised educational contexts of the told time, and I purposefully made the methodological decisions in accordance. My epistemological stance comprises an interpretative paradigm, an approach where 
understanding the context is vital to interpreting data gathered (Kivunja \& Kuyini, 2017). I adopted autoethnography as a research methodology based on the premise that it is "an autobiographical genre of writing and research that displays multiple layers of consciousness, connecting the personal to the cultural” (Ellis \& Bochner, 2000: 739).

\section{Autoethnography as a research method}

A key feature of autoethnography is that it compounds an individual's life story with ethnography which studies a particular social group, white Afrikaner girls (Jarvis, 2015). Allen-Collinson (2013) writes about how the analysis of autoethnographic narratives links the micro-level with the macro-cultural and structural levels in the author's personal lives. Additionally, she discusses embodiment and how the human body must be located within "radically contextual politics; it must focus on the active, agentic flesh-and-blood human body" (Allen-Collinson, 2013: 298), which aligns with the gendered nature of my paper.

Autoethnography is autobiographical and bridges the personal life narrative and the cultural and socio-political dimensions of an individual's lived experiences (Coia \& Taylor, 2010; Lewis \& Wassermann, 2020). Ellis (2004) argues that it is often the voices of the previously silenced or marginalised groups who have begun to bring themselves in from the margins through autoethnographic retelling of experiences set against a specific socio-political background. Formerly silenced, marginalised groups and individuals, have evocative and powerful stories to tell; in this case, one story represents of collective white girlhood. Since autoethnography is research that "makes the experience come alive" (Walker, 2009: 26), silences are shattered in this way, and normative forms of research practices and representations are disrupted. I attempted to break one such silence in the partial literature about white girlhood by sharing and analysing a personal memory of my own experience as a white girl in a history classroom during the apartheid regime.

\section{Data generation and analysis of my narrative}

The data of my study consists of a narrative account of a profoundly personal critical incident in my life. This specific memory was triggered (Arrelano, 2018) by a comment by a colleague made in passing about the shoes I was wearing to work one day. Although the statement was not intended or hurtful in any way, I was immediately again sitting with my back against the wall outside my history classroom in 1989. I then decided to write about this specific incident years ago as part of reflecting journal writing (Erdogan, 2019), which I 
do as a hobby. The more I wrote, the more I started thinking about the place of this incident in our broader society and the significance to educational pedagogy.

While I was writing my story, I was also thinking about my story, and when I analysed the story, I was thinking about my story (Ellis, 2004; Lewis, 2019). I was able to think with, and about my story from a different perspective since I had processed the trauma I experienced at the time, and the memory was now less painful. Through deep thinking, my story gained philosophical meaning. Writing and thinking about the story was liberating as I could remember the incident without the pain and shame I had experienced at the time. This resonates with Chang's (2008) notion of distinguishing between interpretation and analysis in autoethnography. According to her, data analysis entails the identification of the essential features of autoethnography. It also involves the systematic description of the interrelationships between the identified components. On the other hand, data interpretation is about looking deeper into the autoethnographic text to uncover the hidden cultural meaning of a story (Chang, 2008).

\section{My autoethnographic narrative}

The premise of my article is that past dominant Nationalist discourses in education manifested in the micro-contexts of the history curriculum. It is, therefore, fitting that the events described in the autoethnographic account played off in (or outside) the history classroom. The critical incident I describe occurred during 1989 when public history had occupied the school curriculum. In this section, I relate my crucial memory in the form of an autoethnographic retelling of events.

I was born into a white Afrikaner working-class family with a father who worked for the South African government as a fitter and turner at the Department of Water Affairs. Both my parents had completed their schooling up to Grade 9 (then Standard 7). They were then both expected to join the workforce in South Africa to support their respective families. Like many Afrikaner wives, my mother stayed at home to care for my two younger brothers and myself and oversaw the general household. Like in many white Afrikaner families, my father was regarded as the family's traditional breadwinner and my mother as the caregiver. Although my father was at work during the day, he was the protector, provider, and final decision maker regarding managing the family. My mother deliberately inculcated a sense of respect for him by instructing us to be home from wherever we might be, for my father to share a meal with his family after work. His material provision for the family and patriarchal position seemed to earn him respect. Hence, I developed the habit of not contradicting my 
father from a young age, and even when I was an adult, our differences ended in conflict. Though strong in her views, my mother, the soft-spoken white Afrikaner woman, faithfully fulfilled her role of wife and caregiver. Our children regarded her as the confidant with whom we spontaneously shared our problems and our achievements.

Due to my father's occupation at the Department of Water Affairs, I grew up close to water. His work required our family to relocate several times. During my schooling years, when my father completed his water supply projects and his services were required at new sites, we had to move to a new town, house, and school and build new relationships. Due to my family's nomadic lifestyle, I never made permanent relationships with teachers and other learners as I moved from school to school.

In 1989 we relocated to Kirkwood, in the (then) Cacadu district ${ }^{2}$, a small, rural town in the now Eastern Cape situated in the heart of the Sundays River Valley. At the time, I did not know we lived in the Cacadu district, nor why districts' names were important and why they changed later. From a geopolitical point of view, what was important in our lives was the water canal feeding into the $250 \mathrm{~km}$ long Sundays River that ran a few yards behind our house. In the Sundays River Valley, we resided in an area specifically allocated to the families of white working-class people employed by the Department of Water Affairs. All the houses built by the government looked the same. There was a distinct separation between management and workers. The families of the department's management were separated from the workers in that they owned their properties in town. My father did not occupy a managerial position; hence we never had a house in town and resided in the "water affairs camp" where all the houses looked the same.

We usually resided in warm, tropical-like places in South Africa. We experienced warm summers in the Sundays River Valley, which was exquisitely beautiful with citrus fruit orchards across the canal behind our house. My friends mainly included the boys from fellow white working-class families. As a girl, I went against the norm by playing rugby and cycling with the boys in the neighbourhood. I hated shoes and was frequently in and out of the water with my brothers and friends after school. I perceived myself as physically strange at the age of 10 . Everything about my body was, in my view, 'wrong' and different than those

2 In 2015, roughly ten years after apartheid ended, the Cacadu District was renamed as the Saartjie "Sarah" Baartman district, a Khoikhoi woman of historical significance. Sara Baartman (also Saartjie or Sarah) (1789 - 29 December 1815) was the best known of at least two South African Khoikhoi women due to the European objectification of their buttocks' physical features. She was exhibited as a freak show attraction in nineteenth-century Europe under the name Hottentot Venus. "Hottentot" was the name for the Khoi people, now considered an offensive term and "Venus" referred to the Roman goddess of love and fertility, (Shibamoto, 1988). 
of my female friends. I used to dress boyishly merely because it was easier to play several kinds of sports in shorts rather than dresses. My father supported this notion and told my mother numerous times 'to leave the child'. I was often mistaken for a boy, mainly when my hair got wet and curly, which was often the case. I distinctly remember two occasions when strangers approached my parents and told them they had three lovely 'sons'. They would touch my curls, and I was unsure who was most embarrassed by my mother, who had to point out that I was a girl - the stranger or myself. I was barefoot but cushioned and protected by parents, relatives, and a wall of white privilege. There were many things I was unaware of, among others, the political situation and the barefoot children in Kirkwood. They could not afford shoes based on their skin colour and the socio-political situation in which they found themselves due to the apartheid government's legislation.

As a ten-year-old girl, I found myself in a context where there was only one primary school in the town for white children where the medium of instruction was Afrikaans, my home language. I was in Standard 2 (now Grade 4). One summer morning, we were waiting in two neat and silent gender-separate rows for the arrival of our history teacher, $\mathrm{Mr}$ Burns $^{3}$, who was also the principal of the school. Early morning temperatures were already exceptionally high, ranging from 30 - 35 degrees Celsius. Most boys were dressed in their customary white shirts, grey pants, white socks, and black shoes. The girls were dressed more demurely with white school frocks underneath green school dresses and matching ties. Together with black school shoes and long bobby socks, we were meant to be a tidy white picture. I was not wearing school shoes on that specific day as I had played soccer with the boys in the scorching sun during the first break, and it was just too hot to put them back on. I was fully aware that this behaviour was completely out of order for a girl and reserved for certain boys in some cases. I bargained on the extreme heat to save me should my teachers see me. At my school, it was a severe infringement for a girl to be without shoes. In line with the Christian National Education, schools, especially white Afrikaner schools, symbolised order, discipline, rules, tidiness, hard work, and staying in line. The school's motto was, after all, "Arbeid Adel"4 for a specific reason.

When Mr Burns arrived, he immediately noticed my bare white feet while the boys and girls filed alphabetically into the stifling classroom. I was the only girl without shoes. After having been permitted to take our places, he read out the dress code. Mr Burns sent out the barefoot boys with a single command in his dictatorial voice: "All boys not wearing shoes,

3 Pseudonym for the protection of real identity.

4 "Arbeid adel": Translated into English means 'working' and 'nobility'. 
leave the classroom". At least ten barefoot boys left the classroom. Then followed a long lecture about how terrible and worse an offense it was for girls to appear anywhere without shoes. Mr Burns earnestly pointed out that girls should always be dressed appropriately and that it was inexcusable for a girl to show her bare feet. He made it clear that the heat was no excuse at all. If we, the girls, continued this 'wild' and unruly behaviour, we would indeed not become 'proper' women as expected. He was perturbed about our future as 'proper women' and had bought strongly into the idea of the idealised norms ascribed to white Afrikaner women. He stressed that behaviour like this was what got girls 'in trouble', and eventually, they could even end up unmarried and single for the rest of their lives. I was not sure what this trouble entailed, nor did I understand why it would be such a bad idea not to get married. Nothing could alleviate my embarrassment at that moment of the shame that I had brought upon Afrikaner womanhood. Amidst sniggers from my male classmates, I was ordered to leave, and I took my place alongside the barefoot boys outside the classroom.

Since I was the only girl not wearing shoes, I rightly felt the moral scolding was directed at me. My embarrassment was compounded by sniggers, giggling, and fingers pointing to my soil-covered feet by my classmates. If I now recall what bothered me most, it was the fact that Mr Burns never made eye contact with me despite clearly addressing me. At that moment, I thought it would have been more tolerable if he had scolded me directly so that I could do something, apologise, or take the blame in some way.

On that day, Mr Burn's history lesson was on the Anglo-Boer War. ${ }^{5}$ In this war, British soldiers destroyed Boer farms as part of their "Scorched Earth" policy. While I was sitting with the boys outside the classroom under the open window, I could hear Mr Burns teaching about the destruction of crops, the slaughtering and looting of livestock, and the burning down of the Boers homesteads and farms. Thousands of Boer men, women, and children (Mr Burns never mentioned black people's concentration camps) were forcibly moved into concentration camps. The experiences of the Boers, their wives, children, and animals riveted me, as the monotonous voice of $\mathrm{Mr}$ Burns filtered through the windows to the shoeless boys and me. I was sitting with my back against the outside wall of the classroom, listening to Mr Burns telling the story of the struggling Afrikaners, 'my people'.

Trying to relate to the events as they filtered through to us, I felt the walls of an invisible concentration camp ensconcing me. I was imprisoned for the immorality of not wearing

5 The Anglo-Boer War (1899 - 1902), now called the South African War, was fought between the British Empire and two Boer republics, the South African Republic (Republic of Transvaal) and the Orange Free State, over the British Empire's influence in South Africa. 
shoes, unable to escape back into the classroom, which at that moment had captured not only my attention but my entire being. I felt more 'outside' than ever. I was sad, angry, and humiliated at the same time. I wanted to look like my female friends and sit together in the history classroom, making notes with pink pens in books decorated with butterflies. Sitting outside, I intensely related to the women and children in the concentration camps and started to parallel my banishment to theirs. Eventually, I lost complete interest in the humming tone of Mr Burns' voice, and I stopped wearing shoes altogether.

\section{Analysis and discussion of my narrative}

In this section, I analyse and interpret my story through in-depth thinking about my experiences and the context in which it occurred for my account to obtain symbolic and philosophical meaning (Jarvis, 2015; Lewis, 2019). My narrative acquires deeper philosophical and sociological meaning through meta-theorising (Lewis, 2019). I present this section in three moves with 'place' as connecting concept. The concept of 'place' overarches my entire narrative. As a white, female, Afrikaner girl child, I had to know my place and remain in my place.

\section{Place as predominant convergence of identity markers}

The concept of 'place' is central to my narrative and the meaning-making thereof. All my identity markers, namely my female gender, young age, standing in the social strata of my white society, my nationality as a white South African, and my place in a socio-political context by birth, culminated in 'place'. Creswell (2014: 38) says that experiences are never out of context, that we experience things "in place". In my narrative, it is evident that I had occupied several places, different roles, and all of these in a specific place. In all the places I had occupied, I had to know my place and remain in my place, my physical place, and my physical and gendered place as a white Afrikaner girl in the grooming process to become a volksmoeder in my own right. I conceptualise 'place' as my dialogical self, manifesting as a psychological construct that describes the mind's ability to imagine the different positions of participants in an internal dialogue in close connection with an external discussion (Hermans \& Hermans-Konopka, 2010). During my narrative, I was continuously engaged in interlocutory actions and reactions to navigate my young, white, female self within the different contextual places I had occupied. All these interactions took place in predetermined places and from a contextual and social disposition. These places 
were already firmly set and created long before I was born and deeply instilled in the minds of Afrikaner women by literature such as Die Vrou (Albertyn, \& Van der Merwe, 1973).

As the eldest child of a working-class family, I had a particular place in society, which constituted my place in the larger community. There was also the question of my 'place as a child', firstly at home and secondly at school. The children of white Afrikaner families occupied a very stringent place. White families, in my context, considered the English proverb "children must be seen and not heard" seriously. As the child of a strict father, this notion implied a stern order and a clear sense of where I belonged. Casey (2016:8) writes about a "complicating strict father morality", which weighs heavily on Afrikaners and the effects are far-reaching into later life. The respect and reverence children had to demonstrate towards their parents and especially their fathers in hetero-normative, white Afrikaner families extended to teachers, which included my history teacher. I stepped outside my 'place' by not adhering to the school rules and thereby not only violating rules but 'violating' my male teacher through my disobedience.

\section{My place as an outsider within the socio-educational sphere of the 1980s}

The educational arena during the 1980 s was very much an extension of the political context of the time in that education policies were created and enforced as part of the Christian National Education ideologies. The content of learning material, specifically in the history curriculum, consisted of solid messages of Nationalist ideologies (Pingle, 2010; Siebörger, 2018). The hidden curriculum and the academic curriculum were included in all South African classrooms (Siebörger, 2018). The hidden curriculum, which had subtle messages about the Nationalist agenda, were transferred to learners by enforcing norms and values, all in an attempt to strengthen the ideology of Afrikaner nationalism, which was based on the 'chosen people' principle and centred around the Afrikaans language and Christian values (Van der Westhuizen, 2007). The enforcement of this curriculum profoundly influenced me as a white Afrikaner girl child in my history classroom. Mr Burns made sure that I was acutely aware that I was not part of the 'chosen people' by my shoeless behaviour. His lecture directed to me as a girl formed part of the strong but indirect message of the "ideal citizen" (Bertram \& Wassermann, 2015: 156).

My history teacher successfully fulfilled his role as an agent of the state in the history classroom and, through his actions, confirmed the role of the school subject of history as having a "particularly pernicious ideological role under apartheid" (Hues, 2011:74). From 
Mr Burns' position of power, he had the mandate to instil the norms and values of the Nationalist agenda. He did so by shaming me first from a gendered perspective: the fact that I, as a girl, did not wear shoes was a much worse offense than the boys who violated the rule in the same way. By doing so, he elevated the critical roles of the white Afrikaner. It is evident in his comment about his supposed concern about the 'loose' woman I might become if my behaviour did not change. Contrary to certain literary positions, which hold that women were absent from history books, he made sure that I was aware of the vital role of white Afrikaner women, albeit that of a volksmoeder.

Secondly, Mr Burns embarrassed me from a perspective of ideological, social class stratification and, in so doing, fulfilled his role as state agent policing the progress and growth of the superior Afrikaner volk. I did not look like the other girls in my class and did not behave like them. My shoes (in this case, my bare feet) were a symbol of class differentiation. I could not occupy the same space of the accepted 'girlhood' because I would taint the accepted whiteness. More so, I was the child of an uneducated civil servant who resided in state housing and fitted into what could be viewed as lower social strata. My family did not own property, and my father was a mere uneducated skilled worker. In a small primary school consisting of about 120 learners, my history teacher knew this. I was an example of a family or individual who had not yet moved from the "margins of respectability" and was still part of the "racial degeneration" (Van der Westhuizen, 2017: 32). From his perspective, he fulfilled his duty by creating a "superior volk", (Van der Westhuizen, 2017: 32).

To ensure that I conformed as a 'real girl', a girl well on her way to the idealised volksmoeder, he punished me through exclusion from the history classroom, the content, and my female peers, which was a visible act and a lesson for all of us. For the girls dressed and behaved correctly, wore shoes, and showed the emergent, accepted volksmoeder traits, Mr Burns' actions were comforting. He indirectly assured that they were accepted as the insider group. Through wearing shoes, they were upholding Nationalist ideals and belonged somewhere safe. I did not belong to them, but I belonged to the shoeless boys outside the classroom. A dual 'dis-belonging' was created in an embodied way by placing me outside with the boys. I was not part of the collective and 'correct girlhood' inside the classroom, and I did not belong with the boys; hence I was doubly out of place. Extending Mr Burns' policing, he taught me to remain 'in place', but this also served as a veiled warning for the rest of the girlhood of what could happen should you disobey the rules. As I was sitting outside listening to the lesson, I was the picture of the separate development of the white volk. Not all white Afrikaners were equal or treated equally, and there needed to be some 
exclusion to accentuate the fact that there indeed was a volk who was now different and 'better' than previously. My exclusion confirmed the inclusion and status of superior white girlhood.

\section{The place of intersectionality within Nationalist influences}

My narrative displays a strong interrelationship between race, class, and gender. It portrays my racial, class, and gender classification as a white Afrikaner female, how I acted like a girl, and how people reacted. White Afrikaner superiority was enforced through microaggressions in the classroom, in my case, the History classroom. Instead of conforming to the norm by wearing shoes, I contested white Afrikaner girlhood and traditions through my bare feet. I was not good enough to be included in the establishment, so I was excluded from the volk. As determined by the Population Registration Act No. 30 of 1950, the normative physical appearances such as skin colour, hair texture, and other features were extended to include class and gender during apartheid. Maxwell (2021) acknowledged that clothing communicated 'something of sex, occupation, nationality, and social standing. In my case, my history teacher applied sexuality, gender, class, and race as co-constitutive markers in his reaction to my bare feet (Van der Westhuizen, 2017).

I did not conform to the norms of whiteness and ordentlikheid. My bare feet made me unworthy of the white Afrikaner girl and the volksmoeder image. He saw me as low class and not conforming to the norm. I was not worthy of being included in the volksmoeder and ordentlikheid fold. I deserved to be banished in exile as an 'outside insider' by being outside the classroom and Afrikaner ordentlikheid. As Van der Westhuizen (2017) explains, in most nationalisms, women are the bearers of respectability through their bodies, conduct, and clothing. They contribute towards higher civilisation and the decency of a nation. My teacher's action could also be regarded as a social Darwinism - the evolution of cultures. Those at a higher civilised state should assist, through punishment, those who must evolve to the desired level of civilisation.

My history teacher's reaction to my bare feet was also sexually charged by separating me from the other girls. It resonates with Du Toit's (2003: 173) argument that ordentlikheid among Afrikaner females was developed through specific interventions such as differentiation or isolation to 'save' them from the "uncertain edges of whiteness". My bare feet displayed racial and sexual degeneration and even sexual promiscuity and immorality. This was especially evident in Mr Burns' expression of concern about our "future as proper 
women" and that such behaviour might get us "in trouble" and result in not getting married. Through these acts, the National Party ensured that the regulation of sexuality became the foundation of the purity of White women and the production and maintenance of the apartheid nation-state (Klausen, 2010).

My narrative also displays the interplay of class in the manner that my teacher acted towards me. He knew my social status as a working-class child who needed punishment to ensure respectability regarding dress and behaviour. It resonates with Bullen and Kenway (2005) who posit that the underclass is generally associated with images of dependency on the state, teenage pregnancy, crime, an impoverished culture, and a lack of Afrikaner values. Afrikaner nationalism was also an expression of class interests. Van der Westhuizen (2017) posits that respectability was as a key element in the construction of an Afrikaner middle-class.

\section{Final barefoot reflections}

History is not a beauty contest. Emiliano Zapata reminds us that "It is better to die on your feet than to live on your knees". Therefore, our stories about our feet and shoes are important among our other stories from our collective pasts. Ignoring the stories of others causes destruction or violence because the problem with the past is that it does not stay down. If we face the past courageously and share our stories honestly, we create yesterdays with which we can live. In addition, one cannot accept a single yesterday. We need to understand - or at least try to make sense of all yesterday's stories. If we fail to do this, we risk becoming non-persons, less-than-individuals, which results in lives not worth living. Researchers agree that good auto-ethnographies should advance the hope of a better world, with the auto-ethnographer always searching for democracy and social justice (Bochner, 2000; Clough, 2000; Denzin, 2000), appropriately fitting with the intention and aim of this article. The gist of this narrative was about white womanhood and what was expected from girls and the process of becoming a "ordentlike", good white Afrikaner woman in a society dominated by white males. In this study, two 'social groups' were implied: teachers as agents of the state and extensions of church and households who kept the Nationalist ideology intact through micro-aggressive acts, and young, impressionable female children subjected to ideologies upheld by their teachers.

In that critical moment outside the history classroom my questioning and confusion about the two sexes' differential treatment were born. The binary division between boys and girls ran along clear, unperforated lines. There was no in-between. You had to belong 
to one of those, or you were outside - trapped in a third desolate space with no sense of belonging, much like the concentration camps. My history teacher embodied Afrikaans white males in positions of power with whom this was only my first encounter with several to follow. White Afrikaner males became the agents creating these bounded spaces, and in a patriarchal manner, as expected, they favoured boys. White men curated spaces for white boys and dictated the boundaries of the spaces for white females. I was neither in the protected female, nor in the privileged male space.

The demise of apartheid, and in a significant way Afrikanerdom, resulted in destabilisation and confusion about the articulation of white Afrikaner identity (Marx \& Milton, 2011; Van der Westhuizen, 2017). The once, powerful and stable minority of a white Afrikaner population with its own culture and language experienced a perceived marginal and liminal position within the new multiracial and democratic society of South Africa. The fall of apartheid weakened hegemonic articulations such as Afrikaner nationalism (Van der Westhuizen, 2013). During apartheid, Afrikaner identity contributed towards the political, economic, and social development of those who called themselves Afrikaners (Van der Westhuizen, 2017) - to the detriment of those who did not subscribe to the Afrikaner normative of race, class, gender, and sexual orientation. The break from apartheid and white domination necessitated a range of strategies to ensure the integration and survival of Afrikanerdom and its culture within the "rainbow nation" especially for young white Afrikaners (Steyn, 2016). It can thus be argued that the post-apartheid condition 'unsettles culture', and in this case, especially white Afrikaner culture, as it seeks to decentre power, privilege, and normalisation.

In a constitutionally non-racial and non-sexist society, I as a white female, absorbed into Afrikaner nationalism through birth and education, and as a member of the church and cultural organisations, have to reconfigure my identity. Afrikaners find themselves in a "fading position", (Steyn, 2016: 485), within the rainbow nation. The demise of Afrikaner nationalism requires me to redefine my identity as I face my daily tasks as a university lecturer at a former white Afrikaans university, which is still struggling to reform itself regarding race, gender, and class. Again, I feel like the barefoot girl who resists submitting to the volksmoeder ordentlikheid. With my embodied whiteness, I am often on the other side of the table fighting against dominant definitions of ethnic identity, male superiority, racial and sexual discrimination in the forums where I am present. I am critically aware

6 The term rainbow nation was coined by the Nobel Prize winner, and Anglican Archbishop of Cape Town, Desmond Tutu, to describe the post-apartheid multi-racial population of South Africa. 
of the collective guilt, accountability, and collaboration of Afrikaner nationalists to the pain and suffering of those who did not ascribe to the race and ordentlikheid of Afrikaners in the 1980s. I continue to cleanse myself from the stains of selfishness and privileges of nationalism and apartheid that cling to the Afrikaners' identity.

\section{Conclusion}

The focus of my paper was the influence of Nationalist ideologies on girlhood during the apartheid regime in 1989, driven by state agents. In this paper, I referred to state agents as male history teachers who acted as 'vehicles of policing' to ensure the growth and progress towards the purity of the Afrikaner volk. The purpose of my paper was to understand and make meaning of these influences as they manifested in the micro-context of my history classroom. I framed the article theoretically by including the concepts of girlhood studies, the role of white women and girls in the context of Afrikaner nationalism and apartheid. I then discussed autoethnography as a research design and provided a rationale for all methodological decisions. I shared my critical personal memory as a method of data generation, after which I analysed and discussed my narrative by juxtaposing it against relevant scholarly literature. Findings revealed that through an auto-ethnographic process of meaning-making, I realised the liberated position in which I find myself now and how this realisation can inspire a mindset of growth towards a more open stance on social justice and issues of the past.

Further findings pertain to the volksmoeder ideology and our current understanding thereof. It is safe to say that more research into the place of white Afrikaner girls in South African history and how the volksmoeder ideology influenced white girlhood, might prove valuable. I concluded the paper with final, personal reflections. 


\section{References}

Albertyn, C F \& Van der Merwe, C P. 1973. Die Vrou. Stellenbosch: C.F. Albertyn.

Allen-Collinson, J. 2013. Autoethnography as the engagement of self/other, self/culture, self/politics, selves/futures. In: S Holman Jones, TE Adams \& C Ellis. (eds.). Handbook of autoethnography. Walnut Creek, CA: Left Coast Press.

Arellano, A. 2018. Conceal and carry: Communicating about trauma, triggers, and second assaults in the classroom. Unpublished Ph.D. thesis. Nebraska: The University of Nebraska-Lincoln.

Bellerose, M, Diaw, M, Pinchoff, J, Kangwana, B \& Austrian, K. 2020. Pre-pandemic influences on Kenyan girls' transitions to adulthood during covid-19. Girlhood Studies, 13(3):133-150.

Bertram, C \& Wassermann, J. 2015. South African history textbook research: A review of the scholarly literature. Yesterday \& Today, (14):151-174.

Bochner, A P. 2000. Criteria against ourselves. Qualitative Inquiry, 6(2): 266-272.

Bullen, E \& Kenway, J. 2005. Bourdieu, subcultural capital and risky girlhood. Theory and research in education, 3(1):47-61.

Casey, Z. 2016. Strict fathers, competing culture(s), and racialized poverty: White South African teachers' conceptions of themselves as racialized actors. Race Ethnicity and Education, 19(6):1-13.

Clough, P. 2002. Narratives and fictions in educational research (Ser. Doing qualitative research in educational settings). Open University Press.

Coia, L \& Taylor, M. 2010. Co/Autoethnography: explaining our teaching selves collaboratively. In: DL Tidwell, ML Heston \& LM Fitsgerald (eds.). Research methods for the self-study of practice. Ser. Self-study of teaching and teacher education practices. Springer. (9):1316.

Colley, L. (2017). Judging on their looks: understanding pre-service social studies teachers' conceptions of historical agency and gender. Journal of Social Studies Research, 41(2):155166.

Copley, A, Decker, A, Delavelle, F, Goldstein, M, O’Sullivan, M \& Papineni, S. 2020.

COVID-19 pandemic through a gender lens. Available at openknowledge.worldbank.org.

Accessed on 12 July 2021.

Creswell, J W. (2014). Research design: Qualitative, quantitative, and mixed methods approaches (4th ed.). SAGE Publications. 
Curtis, M. 2018. Jews, Antisemitism, and the Middle East. Routledge: New York.

De Beer, M., 2017. A visual and textual re-storying of the diary of Susanna Catharina Smit (1799-1863) (Doctoral dissertation, Stellenbosch: Stellenbosch University).

De Finney, S. 2015. Playing Indian and other settler stories: Disrupting Western narratives of indigenous girlhood, Continuum, 29(2):169-81.

Denzin, NK. 2000. Aesthetics and the practices of qualitative inquiry. Qualitative Inquiry, 6(2):256-265.

Du Preez Bezdrob, AM. 2011. Winnie Mandela: a life. South Africa: Penguin Random House

Du Toit, M. 2003. The domesticity of Afrikaner Nationalism: volksmoeders and the ACVV, 1904-1929. Journal of Southern African Studies, 29(1):155-176.

Duits, L \& van Romondt Vis, P. 2009. Girls make sense: girls, celebrities and identities. European Journal of Cultural Studies, 12(1):41-58.

Ellis, C. 2004. The ethnographic I: A methodological novel about autoethnography. Walnut Creek, CA: Altamira Press.

Ellis, C \& Bochner, A. 2000. Autoethnography, Personal Narrative, Reflexivity: Researcher as Subject, in N. K. Denzin \& Y. S. Lincoln (Eds.), Handbook of Qualitative Research (2nd Ed.), Sage Publications, p. 733-768.

Erdogan, F. 2019. Effect of cooperative learning supported by reflective thinking activities on students' critical thinking skills. Eurasian Journal of Educational Research, 19(80):89112.

Field, C T, Owens, TC, Chatelain, M, Simmons, L, George, A \& Keyse, R. 2016. The history of black girlhood: Recent innovations and future directions. The Journal of the History of Childhood and Youth, 9(3):383-401.

Fogle-Donmoyer, A. 2017. Teaching citizenship \& democracy in a new democracy: pedagogy, curriculum \& teachers' beliefs in South Africa. Unpublished Ph.D. thesis, College Park: University of Maryland.

Giliomee, H. 2009. The Afrikaners: Biography of a people. 2nd ed. Cape Town: Tafelberg. Hermans, H \& Hermans-Konopka, A. 2010. Dialogical self theory. Positioning and counterpositioning in a globalizing society. New York: Cambridge University Press.

Holman Jones, S, Adams, T \& Ellis, C. 2013. Coming to know autoethnography as more than a method. In: S Holman Jones, T Adams \& C Ellis (eds.). Handbook of Autoethnography. Walnut Creek, CA: Left Coast Press.

Hues, H. 2011. "Mandela, the terrorist”: Intended and hidden history curriculum in South Africa. Journal of Educational Media, Memory, and Society, 3(2):74-95. 
Hunter, ND. 2021. In search of equality for women: from suffrage to Civil Rights. Duq. L. Rev., 59:125.

Isaacs, T. 2016. Critical student agency in educational practice: A South African Perspective. Unpublished Ph.D. thesis. Stellenbosch: Stellenbosch University. Jacklin, H. 2001. Teachers, identities and space. Being a teacher: Professional challenges and choices: Reader, 14-28.

Jacobs, JU 2003. Mapping a heartland Breyten Breytenbach's 'Zone of Bastardisation'in Dog Heart. Current Writing: Text and Reception in Southern Africa, 15(2):91-105. Jarvis, B. 2015. Whiteness and education in Southern African spaces: An autoethnography.

Unpublished Ph.D. thesis. Durban: University of KwaZulu-Natal.

Kivunja, C \& Kuyini, AB. 2017. Understanding and applying research paradigms in educational contexts. International Journal of higher education, 6(5):26-41.

Klausen, SM. 2010. “Reclaiming the white daughter's purity”: Afrikaner nationalism, racialized sexuality, and the 1975 abortion and sterilization act in apartheid South Africa. Journal of Women's History, 22(3):39-63.

Levinson, B. 2011. Beyond critique: Exploring critical social theories and education. Boulder: Paradigm Publisher.

Lewis, FA. 2019. Contesting the South African music curriculum: An Autoethnography. Unpublished Ph.D. thesis. Pretoria: University of Pretoria.

Lewis, F \& Wassermann, J. 2020. Ebony and ivory in imperfect harmony-Re-experiencing music education at the University of Cape Town. African Identities, 1-18. Marx, H \& Milton, VC. 2011. Bastardised whiteness:'zef'-culture, Die Antwoord and the reconfiguration of contemporary Afrikaans identities. Social Identities, 17(6):723-745. Maxwell, A. 2021. Analyzing nationalized clothing: nationalism theory meets fashion studies. National Identities, 23(1):1-14.

Maziriri, ET, Mapuranga, M, Tafadzwa, CM \& Nzewi, OI. 2019. Navigating on the key drivers for a transition to a green economy: evidence from women entrepreneurs in South Africa. Entrepreneurship and Sustainability Issues, 7(2):1686.

McLeod, J. (2015). Gender identity, intergenerational dynamics, and educational aspirations:

Young women's hopes for the future. Handbook of children and youth studies, 315-327.

Mendes, K, Silva, K, Duits, L, Zoonen, LV, Lamb, S, Banaji, S \& Edwards, N. 2009. Commentary and criticism, Girls, boys, and "girlhood" studies, Feminist Media studies, 9:(1), 109-125. 
Mitchell, C \& Rentschler, CA. (eds.). 2016. Girlhood and the politics of place. Berghahn Books.

Mitchell, C \& Smith, A. 2020. The lives of girls and young women in the time of COVID-19. Girlhood Studies, 13(3): v-xi.

Msila, V. 2007. From apartheid education to the Revised National Curriculum Statement: Pedagogy for identity formation and nation building in South Africa. Nordic Journal of African Studies, 16(2).

Owens, TC, Callier, DM, Robinson, JL \& Garner, PR. 2017. Towards an

interdisciplinary field of black girlhood studies. Departures in Critical Qualitative Research, 6(3):116-132.

Özkirimli, U. 2000. Theories of nationalism: a critical introduction. Basingstoke: Palgrave.

Pingel, F. 2010. UNESCO guidebook on textbook research and textbook revision. UNESCO.

Prescott, C, Rees, N \& Weaver-Hightower, R. 2021. Enshrining gender in monuments to settler whiteness: South Africa's Voortrekker Monument and the United States' This is the place monument. Humanities, 10(1):41.

Pretorius, SE. 2019. Poor whitism: The fictional volksmoeder in South African novels, 1920s-1940s. Historia, 64(1):65-90.

Siebörger, R. 2018. Public history and the school curriculum: two South African case studies. Public History and School: International Perspectives, 41-54.

Steyn, AS. 2016. Afrikaans, Inc.: The Afrikaans culture industry after apartheid. Social Dynamics, $42(3): 481-503$.

Van der Westhuizen, C. 2007. White Power and the Rise and Fall of the National Party. Cape Town: Zebra Press.

Van der Westhuizen, C. 2013. Identities at the intersection of race, gender, sexuality and class in a liberalising, democratising South Africa: The reconstitution of 'the Afrikaner woman'. Unpublished Ph.D. thesis. Cape Town: University of Cape Town.

Van der Westhuizen, C. 2016. Afrikaners in post-apartheid South Africa: Inward migration and enclave nationalism. HTS: Theological Studies, 72(4):1-9.

Van der Westhuizen, C. 2017. Sitting Pretty: White Afrikaans women in post-apartheid South Africa. Pietermaritzburg: University of KwaZulu-Natal Press.

Van der Westhuizen, C. 2020. (Un) sung Heroines: The rise and fall and rise of the Afrikaner nationalist volksmoeder in South Africa. Matatu, 50(2):258-279.

Vincent, L. 2000. Bread and honour: White working class women and Afrikaner nationalism in the 1930s. Journal of Southern African Studies, 26(1):61-78. 
Walker, A. 2009. A feminist critique of family studies. In: S Lloyd, A Few \& K Allen (eds.). Handbook of feminist family studies Thousand Oaks, CA: Sage. 